\title{
PREFACE TO THE ORIGINAL EDITION
}

$\mathrm{T}$ HIS BOOK is written for amateurs, not professionals. It speaks to the general reader who wants to know what it is that binds together the legal systems of Western Europe and Latin America and that distinguishes them from the legal systems of the AngloAmerican world; to the nonlawyer who wishes to know something about the legal side of European and Latin American culture; to the student seeking collateral reading for a course in history, politics, sociology, philosophy, international relations, area studies, or law. This book may also have some use among lawyers who have not studied foreign and comparative law and wish, for practical or other reasons, to begin to remedy this deficiency. It can provide background reading for persons with public or private business in Europe or Latin America (or other civil law nations). My professional colleagues in foreign and comparative law, however, are likely to find the work too elementary and too general to engage their interest.

Although I have tried to make it clear in the text that this book does not attempt to describe any specific national legal system, a special word should be said here about the peculiar problem posed by France and Germany. Each of these nations has made a major contribution to the civil law tradition, and each still occupies a position of intellectual leadership in the civil law world. At the same time, neither is a "typical" civil law system. Indeed, they are in a sense the least typical of all. The French revolutionary ideology and the French style of codification had only a limited impact on German law. German legal science has never really caught on in France. Elsewhere in the civil law world, however, there has been a strong tendency to receive and fuse both influences. This is particularly true in Mediterranean Europe and Latin America, but it also applies to some extent to most other parts of the civil law world. French or German readers may find much in this book that is not representative of their legal system. The reason is that their system is atypical. The civil law world includes a great number of national legal systems 


\section{Preface to the Original Edition}

in Europe, Latin America, Asia, Africa, and the Middle East. This book is about the legal tradition they share, not about French or German law.

Something should also be said about perspective. I do not mean to suggest that all lawyers in civil law nations accept and believe in those aspects of their tradition that will appear to the reader to be excessive or deficient. On the contrary, I have tried to indicate throughout (and to hammer the point home again in Chapter XIX, which I beg the reader not to skip) that I am describing "prevailing" attitudes. There is the common run of lawyers, and there is the sophisticated, critical jurist at the growing point of legal thought. Sophisticated jurists always constitute the smaller and less representative group, but even in the most backward nation one can expect to find a few lawyers who will honestly say: "I don't think that way at all." In a more advanced civil law nation like France or Germany, the proportion of enlightened and liberated lawyers and the extent to which the legal order has freed itself of the defects of the tradition will be greater. That is another indication of the atypicality of France and Germany. This book, however, is about the way the common run of lawyers in the civil law world generally think, even though the avant-garde of legal thought tells them they are wrong.

Dean Bayless A. Manning of the Stanford School of Law persuaded me that there was a need for this book, and encouraged me to write it. Three outstanding comparative lawyers-Professors Mauro Cappelletti of the University of Florence, F. H. Lawson, formerly of Oxford University, and Konrad Zweigert, of the Max Planck Institute in Hamburg - kindly read the manuscript and suggested a number of changes that improved it. One of my colleagues at Stanford, Dr. George Torzsay-Biber, was particularly helpful on a number of questions concerning Roman civil law. Generations of imaginative and industrious scholars have produced a rich literature on foreign and comparative law, from which most of the ideas contained in this book were drawn. Dr. Hein Kötz, Research Associate at the Max Planck Institute in Hamburg, and Gernot Reiners, a Teaching Fellow at the Stanford School of Law, 1967-68, assisted me in a variety of ways, and in particular gave me authoritative information on German law. Mrs. Lois St. John Rigg prepared the manuscript for publication with skill, patience, and good humor. To all, my thanks.

Stanford, 1969

J.H.M. 
THE CIVIL LAW TRADITION 
This page intentionally left blank 